\title{
Differential Effects of NGF, FGF, EGF, cAMP, and Dexamethasone on Neurite Outgrowth and Sodium Channel Expression in PC12 Cells
}

\author{
Jonathan D. Pollock, ${ }^{a}$ Marie Krempin, and Bernardo Rudy \\ Division of Biology, California Institute of Technology, Pasadena, California 91125, and Department of Physiology and \\ Biophysics, New York University Medical Center, New York, New York 10016
}

\begin{abstract}
PC12 cells are a pheochromocytoma cell line that can be made to differentiate into sympatheticlike neurons by nerve growth factor (NGF). An essential component of the NGFinduced differentiation is the development of action potentials and sodium channels. Using whole-cell clamp we have confirmed that NGF produces a 5- to 6-fold increase in sodium channel density. The sodium channels induced by NGF are not different from those in cells not treated with NGF and are similar to those in other cell types. Basic fibroblast growth factor (FGF), another growth factor that causes PC12 cells to differentiate into sympathetic-like neurons, also produces a 5- to 6-fold increase in sodium current density with channels indistinguishable from those in PC12 cells treated and not treated with NGF. Basic FGF produces the same or somewhat larger increase in sodium channel density but much less neurite outgrowth. In contrast, epidermal growth factor does not produce neurite outgrowth but induces a small, reproducible increase in sodium channel density. Cyclic AMP produces spike-like processes but not neurites and results in a decrease in sodium current and sodium current density. Dexamethasone, a synthetic glucocorticoid, inhibits the increase in sodium current and sodium current density but does not antagonize the neurite outgrowth induced by NGF. Thus, although the increase in sodium channel expression induced by NGF and basic FGF parallels the changes in morphology that lead to neurite outgrowth, it clearly does not depend on them. The results show that different aspects of neuronal differentiation might be independently regulated by the microenvironment.
\end{abstract}

PC12 cells are a clonal cell line derived from a transplantable pheochromocytoma tumor in New England Hospital Deaconess rat (Greene and Tischler, 1976) with characteristics similar to precursors of adrenal gland cells. When grown in the presence of nerve growth factor (NGF), the cells differentiate into sympathetic-like neurons: The cells stop dividing, sprout neurites,

\footnotetext{
Received Aug. 14, 1989; revised Mar. 13, 1990; accepted Mar. 23, 1990.

Part of this work was done in the laboratory of Dr. Mark Tanouye. We wish to thank Mark Tanouye for his most generous support of this work. We would also like to thank Dr. Norman Davidson for allowing us to use his tissue culture facilities. This work was supported by NRSA Fellowship 2 F 32 NS07903-03 to J.D.P., by NIH Grant GM 26976 to B.R. and by the Pfeiffer Research Foundation and USPHS Grant NS21327 to Dr. Mark Tanouye.

Correspondence should be addressed to Bernardo Rudy, Department of Physiology and Biophysics, New York University Medical Center, 550 First Avenue, New York, NY 10016.

a Present address: Department of Human Genetics-HHMI, University of Utah, Salt Lake City, UT 84112.

Copyright (C) 1990 Society for Neuroscience $0270-6474 / 90 / 082626-12 \$ 03.00 / 0$
}

and becomc clcctrically excitable (Greene and Tischler, 1976; Dichter et al., 1977; Rudy et al., 1982).

In the course of differentiation of PC1 2 cells by NGF, a number of early and late events are activated (Greene and Tischler, 1982; Greene, 1984). Early events are characterized by their rapid onset, usually occurring within minutes, whereas late events start to be observed between 24 and $48 \mathrm{hr}$. Many of the early events are transcriptionally independent, while the late events are frequently transcriptionally dependent. An example of an early event is the rapid change in the surface topography after the addition of NGF. These early morphological events (Connolly et al., 1979, 1984) are temporally associated with hydrolysis of phosphoinositides (Contreras and Guroff, 1987), activation of N-kinase (Rowland et al., 1987), changes in protein phosphorylation (Halegoua and Patrick, 1980; Yu et al., 1980; End et al., 1983; Landreth and Rieser, 1985; Cremins et al., 1986), and increased uptake of nutricnts (McGuire and Greene, 1979). Interestingly, a number of early genes are induced by NGF. For example, Greenberg et al. (1985), Curran and Morgan (1985), Kruijer et al. (1985), and Milbrandt (1986) have observed a rapid increase in c-fos, a cellular oncogene and a transcription factor (Distel et al., 1987; Curran and Franza, 1988), peaking 15 min after the addition of NGF to PC12 cells. It is possible that c-fos acts as an intermediary for the late differentiation of PC12 cells by NGF.

Examples of late events induced by NGF are the outgrowth of neurites, the development of small vesicles that form in varicosities, and the development of electrical excitability. Late events also include the induction of several neuron-specific proteins such as GAP-43 (Basi et al., 1987; Karns et al., 1987), acetylcholinesterase (Lucas et al., 1980; Rieger et al., 1980), SCG-10 (Stein et al., 1988), Thy-1 (Richter-Landsberg et al., 1985; Dickson et al., 1986), NILE (Salton et al., 1983), MAP 1, and Tau (Drubin et al., 1985), 68K and other neurofilament proteins (Lee and Page, 1984; Dickson et al., 1986), VF8a (Levi et al., 1985), synapsin (Romano et al., 1987), and peripherin (Aletta et al., 1988), as well as the induction of a set of inducible clones (Leonard et al., 1987). Key to the development of electrical excitability is the transcriptionally dependent induction of TTX-sensitive sodium channels (Kirschenbaum et al., 1987; Mandel et al., 1988; C. Kentros, T. P. Snutch, M. Berger, et al., unpublished observations). The steady-state levels of sodium channel mRNA reach their peak within 2-3 hr after the addition of NGF but action potentials are not seen until after several days. Moreover, the increase in mRNA levels can be blocked by protein synthesis inhibitors (Kentros, Snutch, Berger, et al., unpublished observations).

Recently, acidic and basic fibroblast growth factor (FGF; see 
Gospodarowicz, 1986, for review) have been found to produce many of the same effects as NGF on PC12 cells (Togari et al., 1985; Wagner and D'Amore, 1986; Neufeld et al., 1987; Rydel and Greene, 1987; Schubert et al., 1987) and on chromaffin cells (Claude et al., 1988; Stemple et al., 1988). In PC12 cells, FGF has been found to induce neurite outgrowth, to producc phosphorylation of tyrosine hydroxylase, to induce MAP 1, Thy-1, and NILE, and to increase acetylcholinesterase activity (Rydel and Greene, 1987). This suggests that NGF and FGF acting at different receptors share some of the same signal-transduction pathways. In contrast, other factors such as epidermal growth factor (EGF) and cAMP lead to some of the early events such as protein phosphorylation and induction of c-fos but do not produce morphological differentiation (Connolly et al., 1984; I ee and Page, 1984; Leonard et al., 1987).

The effects of growth factors on PC12 cells are thought to be representative of the events that occur during neuronal differentiation, particularly for cells that derive from the neural crest. Adrenal chromaffin cells and sympathetic neurons are derived from the neural crest. The microenvironment of the neural crest determines whether the cell will become a sympathetic neuron or an adrenal chromaffin cell (Le Douarin, 1980, 1982). In the presence of NGF, the cell becomes a sympathetic neuron and in the presence of glucocorticoids, the cell becomes a chromaffin cell (Landis and Patterson, 1981). Adrenal chromaffin cells treated with NGF have been observed in culture to become sympathetic neurons as late as the neonatal stage (Doupe et al., 1985). The differentiation of neonatal adrenal chromaffin cells into sympathetic neurons by NGF can be antagonized by the synthetic glucocorticoid, dexamethasone (Unsicker et al., 1978; Tischler et al., 1982; Doupe et al., 1985). It follows, therefore, that NGF is activating a set of genes that gives the cell its neuronal phenotype and glucocorticoids act to inhibit these genes. However, in PC12 cells morphological differentiation by NGF is not antagonized by glucocorticoids (Greene and Tischler, 1976), while a number of mRNA transcripts induced by NGF are inhibited (Leonard et al., 1987; Federoff et al., 1988; Stein et al., 1988). This suggests that transcription of gene products involved in neurite outgrowth is no longer under the control of glucocorticoid-responsive elements in PC12 cells. Alternatively, steps subsequent to transcription, controlling steady-state transcript levels and amount of functional protein, are not responsive to glucocorticoids in these cells.

Since induction of sodium channels is a key feature of the late neuronal-like differentiation by NGF, in this paper we address the following questions: (1) Do other agents such as FGF, EGF, and cAMP that produce many of the early events produced by NGF, induce sodium channels either with electrophysiological properties identical to or different from those produced by NGF? (2) Is the increase in sodium channels by NGF as unaffected by dexamethasone as is neurite outgrowth? (3) To what degree does sodium channel induction correlate with morphological differentiation? These studies are important to understand the mechanisms that regulate sodium channel expression and suggest factors that may regulate neuronal excitability in vivo. The comparison of the effects of different agonists that influence PC12 cells may shed light on the control and coordination of different components of neuronal differentiation, e.g., neuronal excitability and morphological differentiation. Such investigations may lead to suggestions about specific intracellular messengers that regulate individual aspects of the neuronal phenotype.

\section{Materials and Methods}

Tissue culture. PC12 cells were cultured according to the method described by Greene et al. (1987). Briefly, PC12 cells, passage 29-45, were grown in RPMI with $10 \%$ horse serum heat inactivated at $56^{\circ} \mathrm{C}, 5 \%$ fetal calf serum, $25 \mathrm{U} / \mathrm{ml}$ penicillin, and $25 \mu \mathrm{g} / \mathrm{ml}$ streptomycin on rat tail collagen in $35-\mathrm{mm}$ petri dishes (Falcon). The cells were fed every other day and passaged about once every week. These culture conditions were maintained when $300 \mu \mathrm{M}$ 8-chlorophenylthio-cyclic adenosine monophosphate (8-CPT-cAMP, Boehringer Mannheim), $10 \mathrm{ng} / \mathrm{ml} \mathrm{EGF}$ (generous gift of Frederick Maxfield, Dept. of Pathology,. College of Physicians and Surgeons, Columbia University, New York, NY), or 5 $\mu \mathrm{M}$ dexamethasone (Sigma, St. Louis, MO) was added. When cells were treated with $50 \mathrm{ng} / \mathrm{ml} \mathrm{NGF}$ [2.5 S NGF was purified from mouse submaxillary gland according to the method of Mobley et al. (1976)] or 10 $\mathrm{ng} / \mathrm{ml}$ bovine basic FGF (generous gift of Barbara Wold, Division of Biology, Caltech), the cells were grown in RPMI supplemented with $1 \%$ horse serum unless otherwise stated. We confirmed that NGF increased sodium current and sodium current density by the same amount in cells grown in either $10 \%$ horse serum and $5 \%$ calf serum or just $1 \%$ horse serum.

Electrophysiology. PC1 2 cells were patch-clamped in either the wholecell or outside-out configuration, according to the method of Hamill et al. (1981) using an EPC-7 patch clamp (I ist Flectronics, Greenville, NY) on a Nikon Diaphot inverted microscope (Garden City, NY) fitted with Hoffman interference contrast optics. The current signals from the patch clamp were filtered at $2200 \mathrm{~Hz}$ with a low-pass 8-pole Bessel filter (Frequency Devices, Haverhill, MA). The experimental protocol and data acquisition were run on an IBM XT or AT computer using PClamp software (Axon Instruments, Burlingame, CA). When recording, the cells were bathed in a saline solution containing (in $\mathrm{mm}$ ) $140 \mathrm{NaCl}, 2.8$ $\mathrm{KCl}, 1 \mathrm{CaCl}_{2}, 2 \mathrm{MgCl}_{2}, 10$ Hepes- $\mathrm{NaOH}, \mathrm{pH}$ 7.2. To block outward currents the pipette solution consisted of (in mM) $120 \mathrm{CsCl}, 20 \mathrm{TEACl}$, $1 \mathrm{CaCl}_{2}, 2 \mathrm{MgCl}_{2}, 11$ EGTA, 10 Hepes-KOH, pH 7.2. The pipettes were pulled from VWR 100 lambda pipettes made of borosilicate glass and typically had resistances of $1-4 \mathrm{M} \Omega$. Just prior to obtaining a gigaseal, the junction potential was zeroed. Membrane area was estimated from measurements of cell capacitance, assuming a specific capacitance of $1 \mu \mathrm{F} / \mathrm{cm}^{2}$. The capacitance was measured from the integral of the capacity transient for a $10 \mathrm{mV}$ depolarizing pulse from a holding potential of $-90 \mathrm{mV}$.

\section{Results}

$N G F$ and FGF produce neurite outgrowth and induce sodium channels

Figure 1 compares the effect of NGF and basic FGF on morphology with the amount of sodium current present in cells treated with the factors for 0,2 , and $10 \mathrm{~d}$. By $2 \mathrm{~d}$, cells treated with either NGF or basic FGF have begun to develop neurites and show an increase in sodium current. The magnitude of the sodium current as well as the density and length of neurites continues to increase as seen at $10 \mathrm{~d}$ of treatment with NGF or basic FGF. As shown in Figure 1, the density of neurites is much higher in NGF-treated cells than in basic FGF-treated cells. In addition, after $10 \mathrm{~d}$ of treatment, the neurites of cells treated with basic FGF are somewhat narrower and straighter than those in cells treated with NGF (see also Rydel and Greene, 1987). Although on average the sodium current in NGF-treated cells is somewhat greater than in cells treated with basic FGF (2194 $\pm 373 \mathrm{pA}$, mean $\pm \mathrm{SEM}, n=12$, vs $1795 \pm 206 \mathrm{pA}$, mean \pm SEM, $n=24$ ), the sodium current density is a little greater in cells treated with basic FGF than NGF $\left(143 \pm 13 \mu \mathrm{A} / \mathrm{cm}^{2}\right.$, mean $\pm \mathrm{SEM}, n=24$, vs $119 \pm 14 \mu \mathrm{A} / \mathrm{cm}^{2}$, mean $\pm \mathrm{SEM}, n=12$ ).

\section{Effect of CAMP and EGF on ionic currents and morphology}

Figure 2 compares the effects of 2 other agents, cAMP and EGF, on sodium currents and cell morphology. EGF causes an in- 


\section{A}

CONTROL

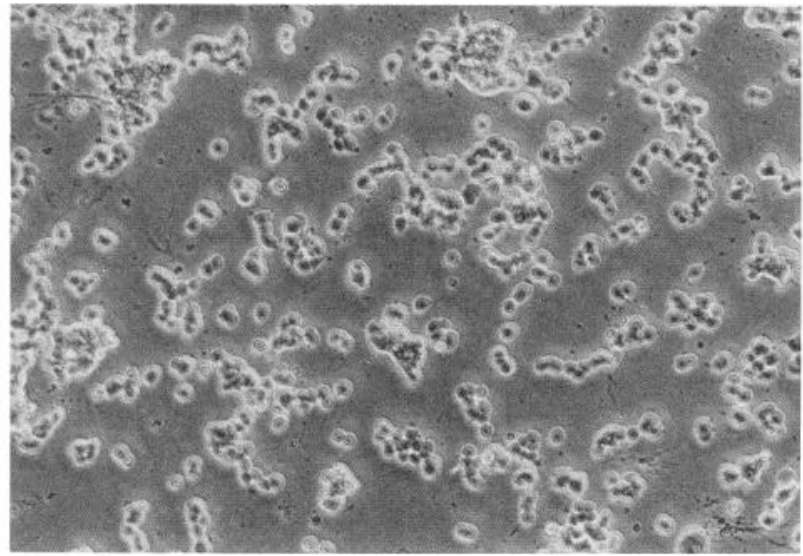

\section{DAYS NGF}

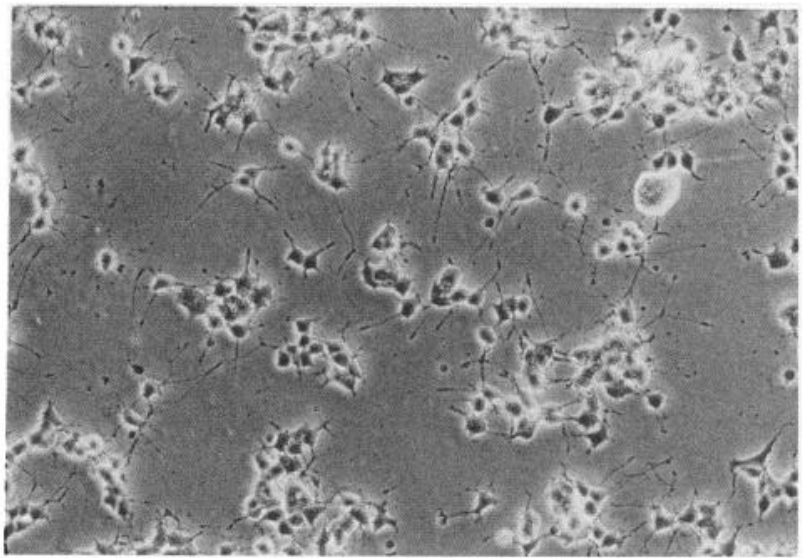

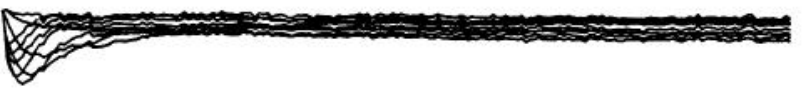

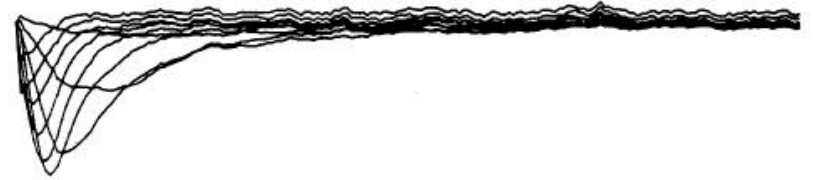

\section{DAYS NGF}
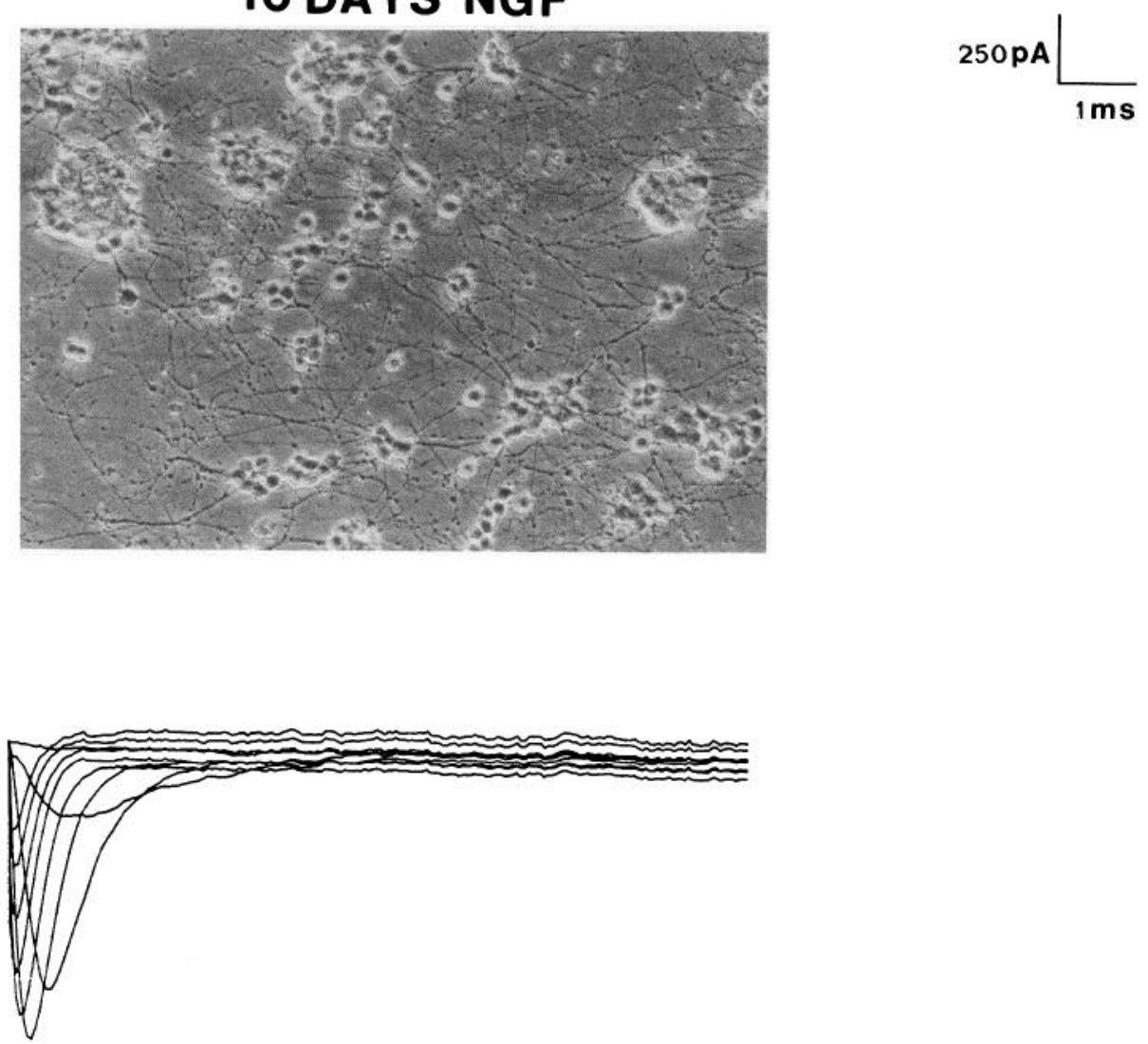

Figure 1. Effect of NGF $(A)$ and basic FGF $(B)$ on PC12 cell morphology and ionic currents. PC12 cell cultures were treated for 0,2 , or $10 \mathrm{~d}$ with NGF or basic FGF as described under Materials and Methods. Records are from sample cells under whole-cell patch clamp after blocking potassium currents as described under Materials and Methods. The cells were held at $-90 \mathrm{mV}$, and depolarizing commands were given in $10 \mathrm{mV}$ increments until $+40 \mathrm{mV}$ was reached. 
B

CONTROL
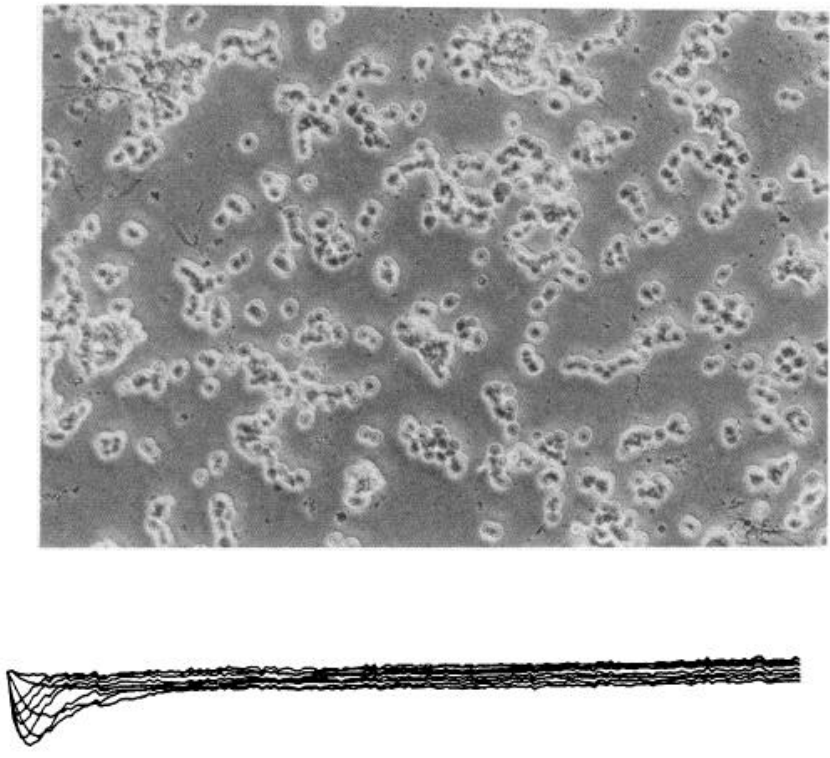

\section{DAYS bFGF}
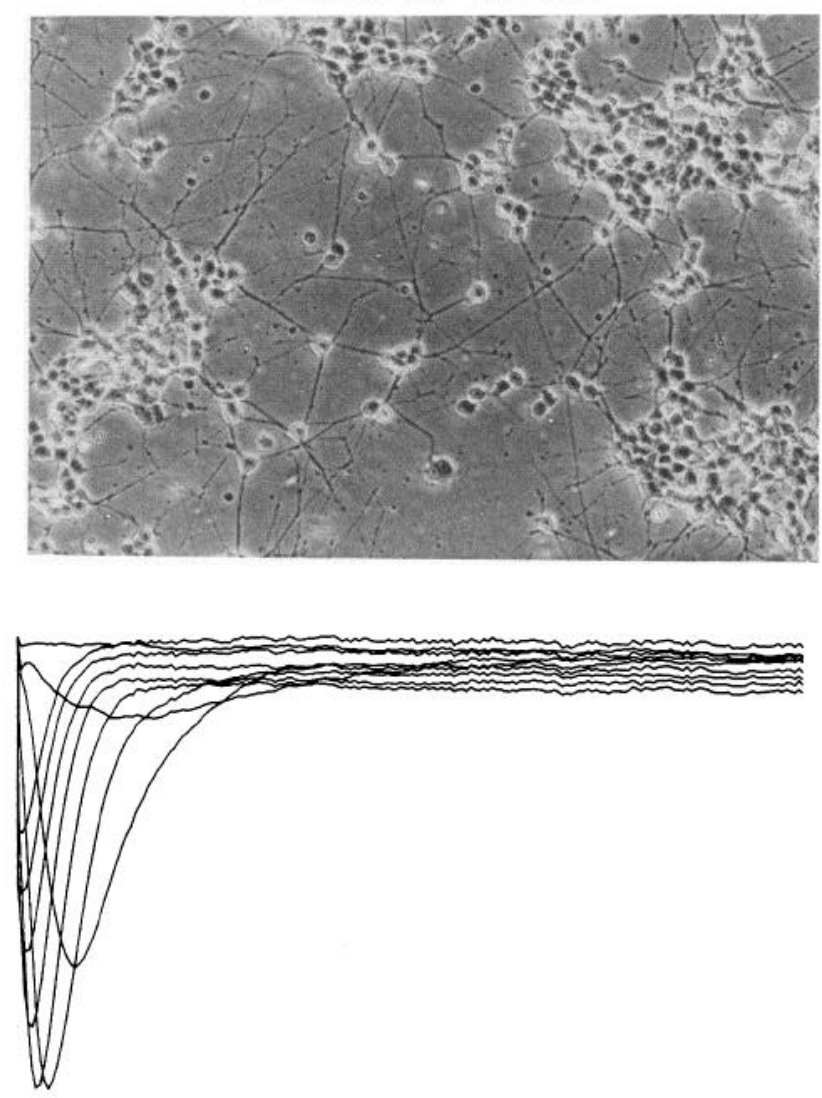

\section{DAYS bFG F}
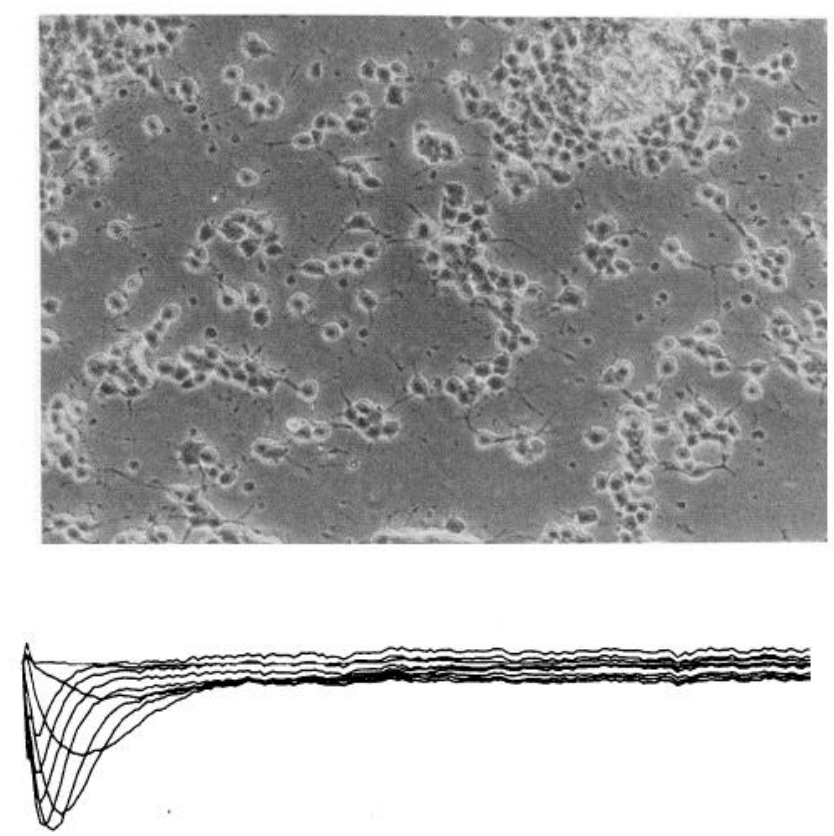

250pA

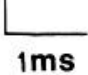




\section{A}

\section{CONTROL}

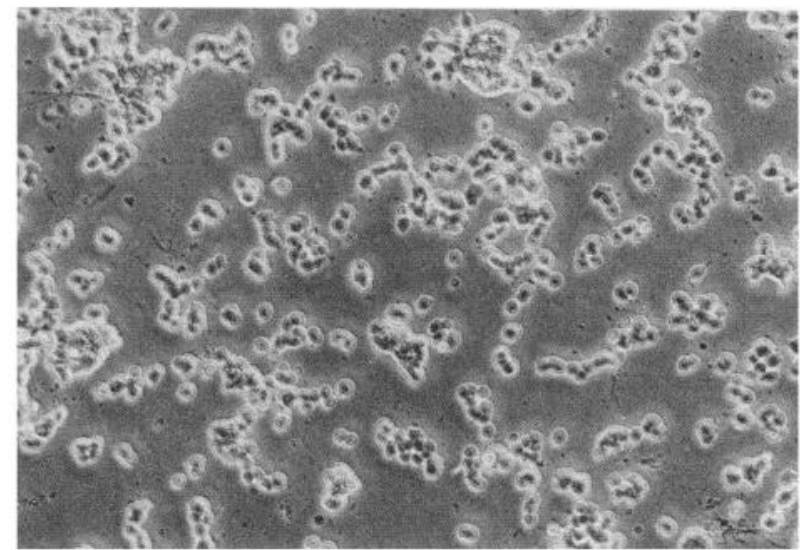

\section{DAYS EGF}

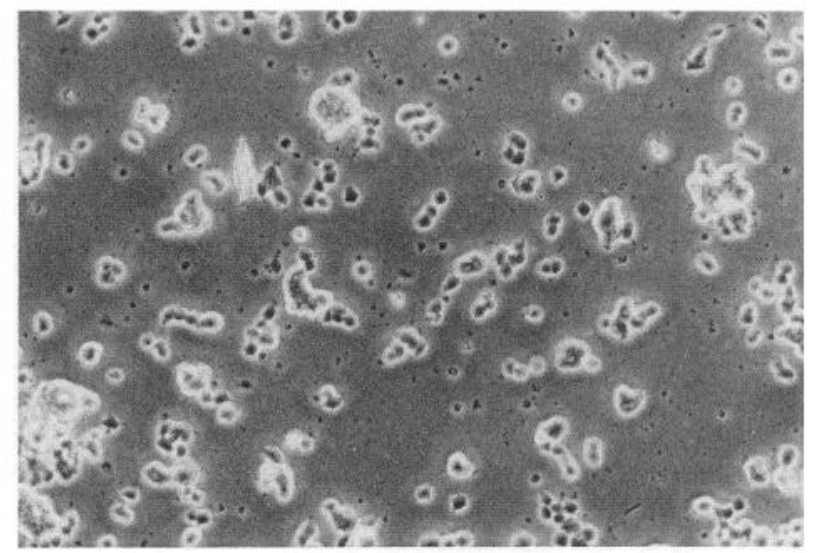

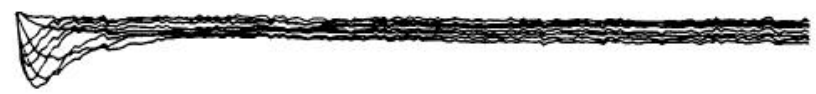

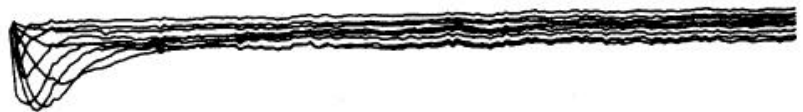

\section{DAYS EGF}
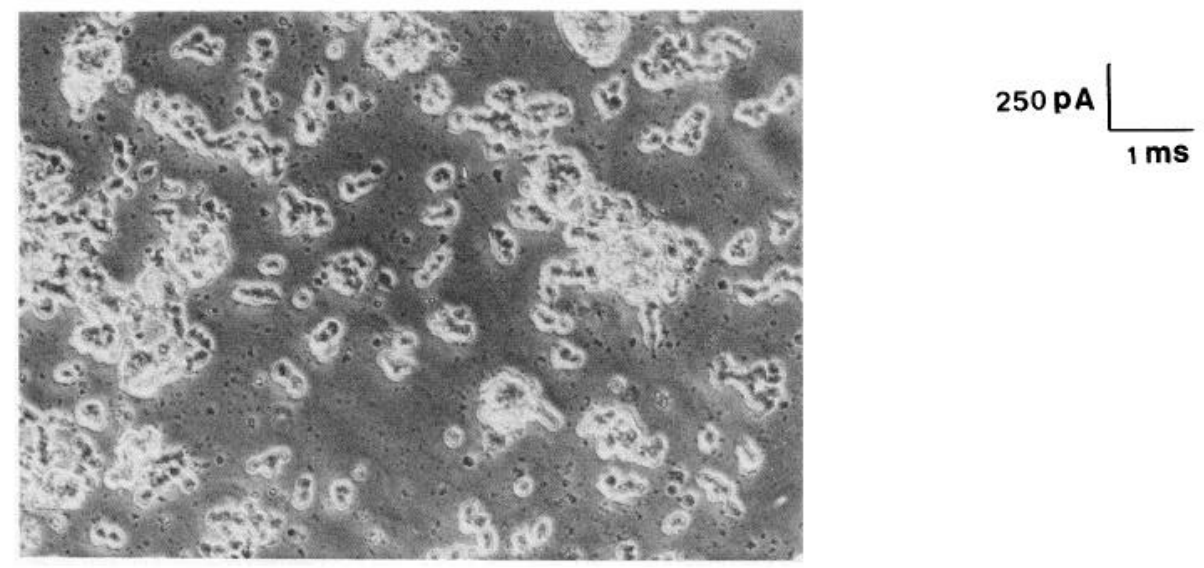

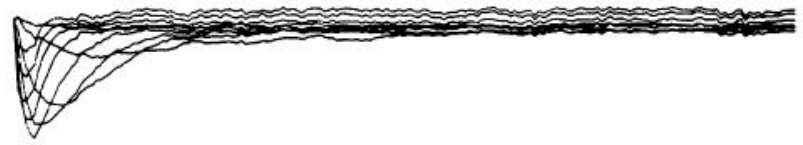

Figure 2. Effects of EGF $(A)$ and cAMP $(B)$ on PC12 cell morphology and ionic currents. PC12 cell cultures were treated for 0,2 , or $10 \mathrm{~d}$ with EGF or CPT-cAMP as described under Materials and Methods. Records are from sample cells under whole-cell patch clamp after blocking potassium currents as described under Materials and Methods. The cells were held at $-90 \mathrm{mV}$, and depolarizing commands were given in $10 \mathrm{mV}$ increments until $+40 \mathrm{mV}$ was reached.

crease in the rate of cell division without any significant change in morphology (Fig. 2A). However, there is a modest increase in both sodium current and sodium current density that appears to be time dependent. At $10 \mathrm{~d}$, the sodium current and sodium current density for EGF-treated cells were the same as that produced by NGF and basic FGF at $2 \mathrm{~d}$. On the other hand, cAMP produces only spike-like processes that become apparent at $2 \mathrm{~d}$ (Fig. $2 B$ ). As the spike-like processes appeared, the sodium 


\section{B}

\section{CONTROL}
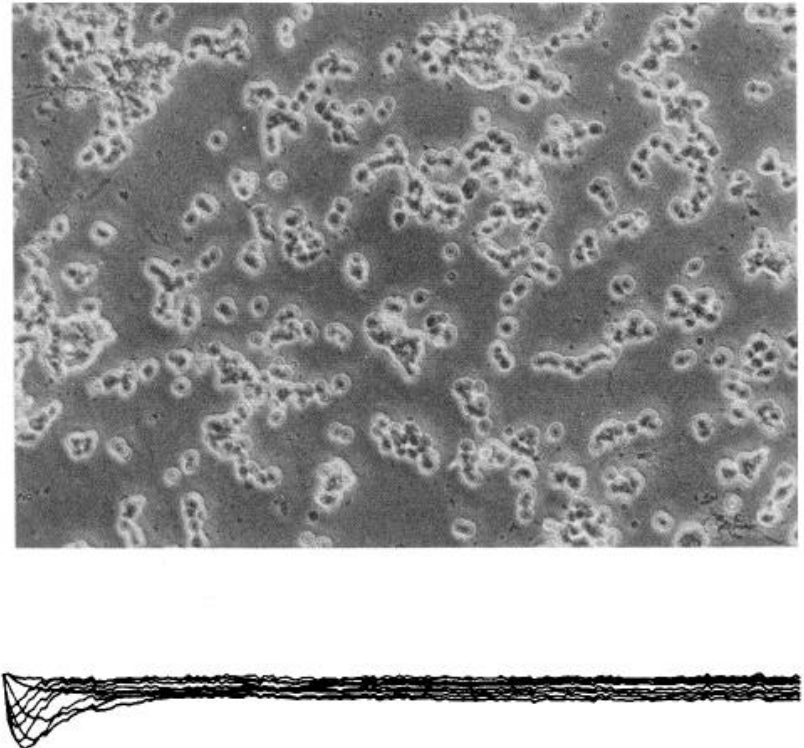

\section{DAYS CAMP}
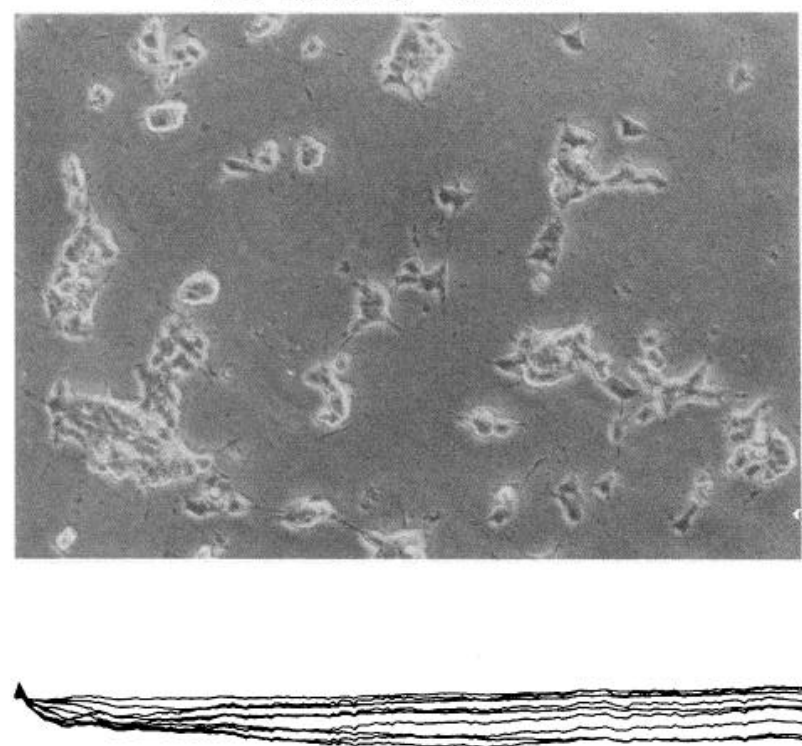

Figure 2. Continued.

current began to disappear with an increase in calcium current. After a $10 \mathrm{~d}$ treatment, sodium currents are undetectable, but there is a significant increase in calcium current. The results of the effects of EGF, cAMP, NGF, and basic FGF on sodium current and sodium current density for several experiments are summarized in Figure 3. As shown in Figure 3, the small timedependent increase in sodium current and sodium current density with EGF is reproducible.

\section{DAYS CAMP}
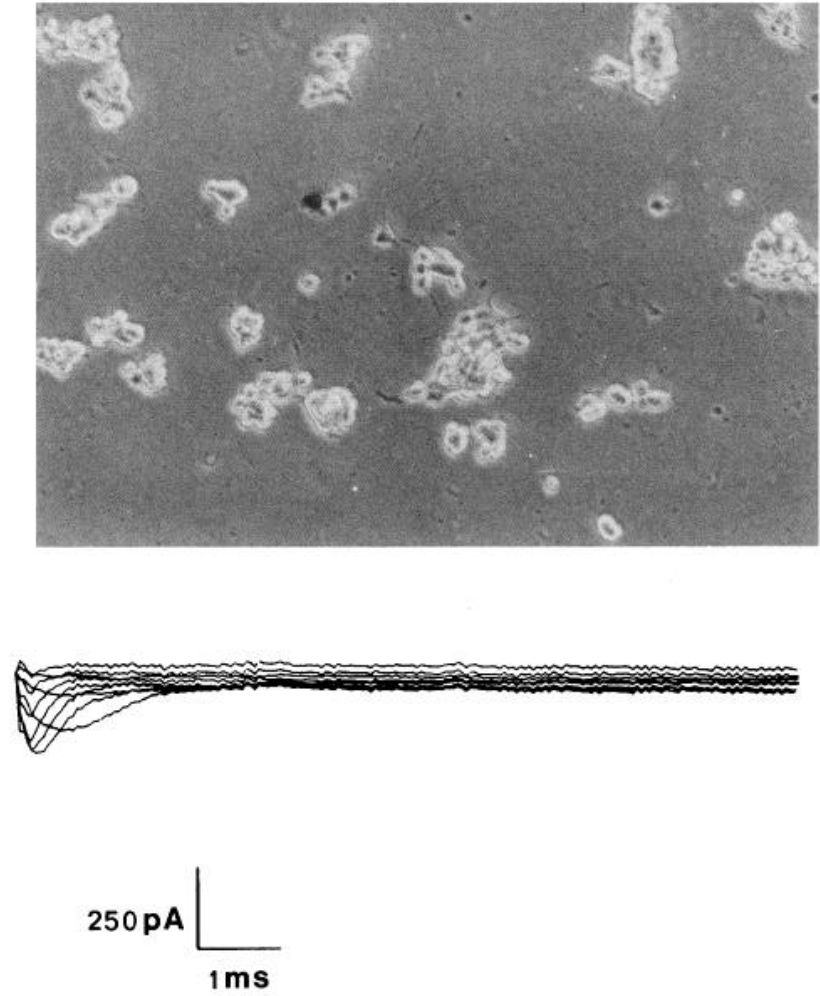

Electrophysiological properties of sodium channels induced by $N G F$ and $F G F$

Figures 4 and 5 illustrate the functional properties of sodium channels in untreated and NGF-treated PC12 cells in which potassium currents have been blocked. The amount of sodium current present in NGF untreated cells is quite variable. In $60 \%$ of the cells studied thus far $(n=78)$ sodium currents were not 

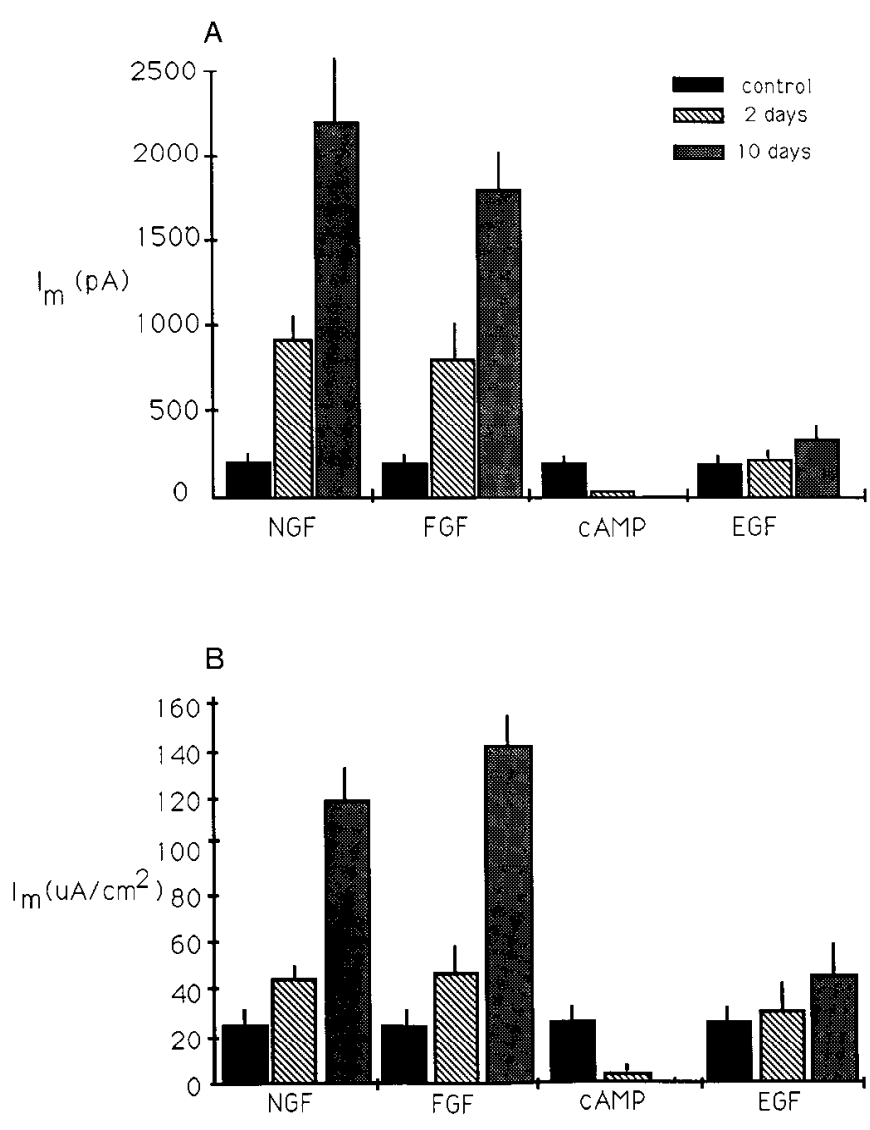

Figure 3. Mean effect of $50 \mathrm{ng} / \mathrm{ml} \mathrm{NGF}(n=24) ; 10 \mathrm{ng} / \mathrm{ml}$ basic FGF $(n=12) ; 300 \mu \mathrm{M}$ CPT-cAMP $(n=11) ;$ and $10 \mathrm{ng} / \mathrm{ml} \mathrm{EGF}(n=13)$; on the magnitude of the peak sodium current $(A)$ and peak sodium current density $(B)$. Control cells, $n=23$ : Error bars: SEM.

detected. In the remaining cells, variable amounts of sodium current (20-150 pA of maximum peak sodium current) were observed (Fig. $4, A-C$ ). In 3 of the cells studied we have also observed approximately $800 \mathrm{pA}$ of maximum peak sodium current (not shown). In contrast, long-term treatment with NGF $(10-14 \mathrm{~d}, n=49)$ results in a more homogeneous cell population with respect to sodium current levels. Almost $100 \%$ of the cells exhibit more than $1000 \mathrm{pA}$ of maximum peak sodium current. The amount of sodium current ranges between 900 to $2500 \mathrm{pA}$. A typical PC12 cell treated with NGF for 2 weeks is shown in Figure $4 D$. The properties of the sodium currents are very similar before and after NGF treatment. The voltage dependence of activation and inactivation (Fig. 5, $A-C$ ) and the time constants of inactivation (Fig. $5 D$ ) are all very similar before or after NGF treatment. In a separate set of expcriments we compared the kinetics of the sodium current induced by NGF with the sodium current induced by basic FGF. The sodium currents induced by NGF and FGF have similar current-voltage characteristics and steady-state inactivation curves and are both completely blocked by 100 nM TTX (data not shown).

To further analyze the kinetic characteristics of the sodium channels induced by NGF and by FGF, single sodium channel records were obtained. During $25 \mathrm{msec}$ depolarizations from a holding potential of $-90 \mathrm{mV}$, inward channels are observed which activate rapidly and usually inactivate within the first 2 msec. When single-channel records are averaged, the current has kinetic characteristics similar to the macroscopic sodium current. The single sodium channel records show an average conductance of $11 \mathrm{pS}$, both for NGF- and basic FGF-treated cells, as well as for untreated cells (data not shown).

\section{Dexamethasone suppresses sodium current induction but not neurite growth}

We find (Figs. 1, 2) that the degree of neurite outgrowth does not always correlate with the amount of sodium channel induction. Whereas neurite outgrowth is significantly weaker with FGF treatment, sodium channel induction is similar or even greater with FGF than with NGF. Furthermore, EGF produces a small increase in sodium channels but no neurite outgrowth. The effects of dexamethasone on NGF-induced sodium currents and morphology described below also show a dissociation between the regulation of neurite growth and sodium channel expression.

Figure 6 shows that dexamethasone in the presence of NGF does not prevent neurite outgrowth; as shown in Figure 7, however, dexamethasone inhibits the NGF induced increase in sodium current and sodium current density. The small increase in sodium currents (Fig. $7 A$ ) in the presence of dexamethasone and NGF compared to control cells is due entirely to an increase in membrane area $\left(13.5 \pm 3.2 \times 10^{-6}\right.$ vs $\left.7.8 \pm 2.1 \times 10^{-6} \mathrm{~cm}^{2}\right)$ and therefore does not reflect an increase in sodium channel density (Fig. $7 B$ ). No significant effect on either sodium current or sodium current density was observed with $5 \mu \mathrm{M}$ dexamethasone alone.

\section{Discussion}

We have previously shown that except for the appearance of a small population of TTX-resistant sodium channels in PC12 cells grown under certain conditions (Rudy et al., 1987), the sodium channels present in $\mathrm{PC} 12$ cells before and after longtcrm NGF trcatment arc indistinguishable. The electrophysiological studies shown here confirm and extend these observations. The amount of sodium current found here can account for the quantitative measurements of functional sodium channels or STX binding sites that have been reported in PC12 cell populations (Rudy et al., 1982, 1987). However, as shown here, these numbers reflect the averages of cells with diverse properties, particularly in PC12 cells not treated with NGF. The majority of cells not treated with NGF seem to lack functional sodium channels (Fig. 4). Therefore, in those undifferentiated cells where sodium current is lacking, the size of sodium channel induction by NGF is significantly greater than the average reported for cell populations.

Like NGF, FGF has been found to affect the survival and differentiation of neurons in the central and peripheral nervous systems (reviewed in Logan and Logan, 1986; Barde et al., 1989), and to induce neurite outgrowth in PC12 cells (Togari et al., 1985; Wagner and D'Amore, 1986; Rydel and Greene, 1987; Neufeld et al., 1987; Schubert et al., 1987). This is the first report showing that FGF can also induce sodium channels and thus that it may influence neuronal excitability. The sodium channels induced by FGF have electrophysiological characteristics indistinguishable from those induced by NGF. This suggests that FGF and NGF acting at different receptors (Togari et al., 1985) either share some signal-transduction pathways or have a transduction pathway that converges to activate the same late events, i.e., morphological differentiation and sodium channel induction.

In contrast to NGF and FGF, EGF and cAMP, agents that produce some of the early events of NGF and FGF, produced 

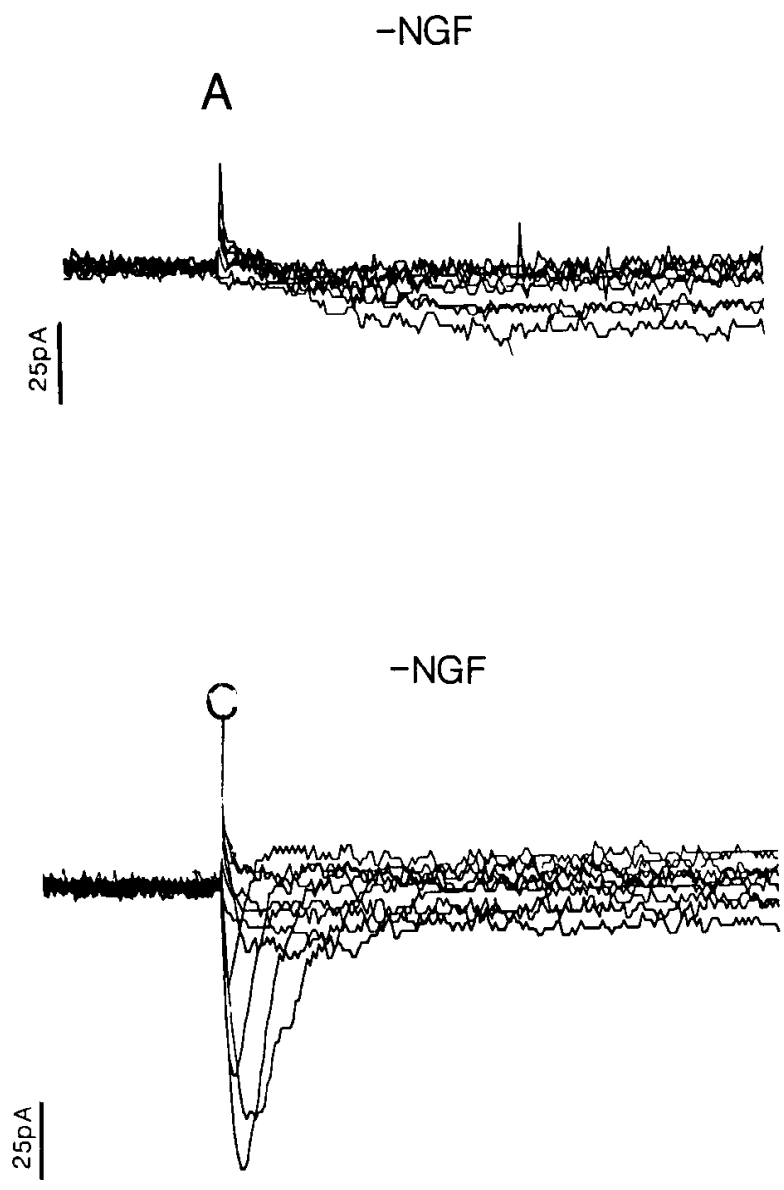
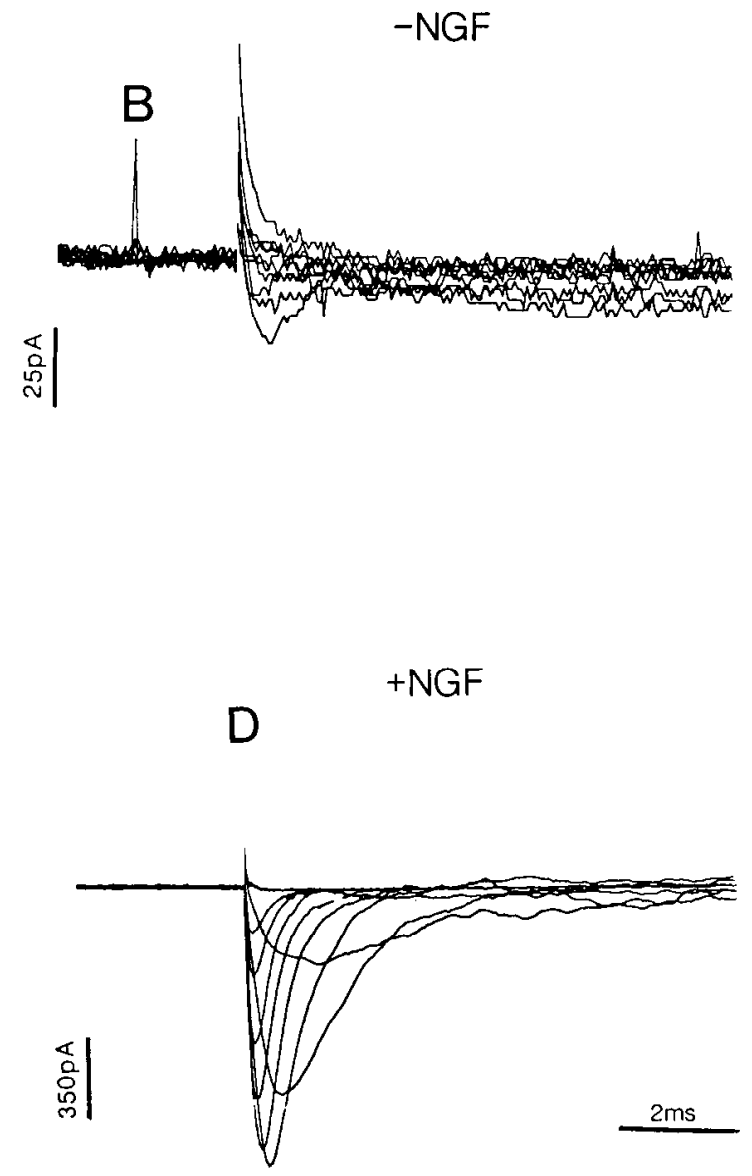

Figure 4. Sodium and calcium currents in PC12 cells. Records obtained in the whole-cell clamp configuration of the patch-clamp technique as described under Materials and Methods. $A-C$, Cells grown in the absence of NGF; $D$, cells grown in the presence of NGF for $14 \mathrm{~d}$. The membrane potential was held at $-80 \mathrm{mV}$, and depolarizing pulses were applied from $-50 \mathrm{mV}$ to $+50 \mathrm{mV}$ in $10 \mathrm{mV}$ increments. Potassium currents were blocked as described under Materials and Methods.

little or no increase, respectively, of sodium current and sodium current density. Sodium channel mRNA induction by NGF in PC12 cells depends on protein synthesis (Kentros et al., 1990), suggcsting that an intermediary protein is required to activate the sodium channel gene. The product of an early immediate gene such as c-fos induced by NGF and FGF (Greenberg et al., 1985; Curran and Morgan, 1985; Kruijer et al., 1985; Milbrandt, 1986) might be a good candidate. However, the results of the experiments with EGF and cAMP, agents known to also elevate c-fos (Greenberg et al., 1985), suggest that the elevation of c-fos, if necessary, is not sufficient by itself to activate sodium channel transcription.

The time course of sodium channel induction by NGF and FGF parallels the time course of morphological differentiation induced by these agents. However, we find that FGF produces a similar or even greater increase in sodium channel density than NGF, despite its much weaker ability to induce neurite outgrowth. We also find that EGF produces a small increase in sodium channel density but no neurite outgrowth. Thus, the same density of sodium channcls is found in cells treated with NGF for $2 \mathrm{~d}$, with FGF for $2 \mathrm{~d}$, or with EGF for $10 \mathrm{~d}$. However, the resulting cells differ markedly in morphology, with many, few, and no neurites, respectively. Furthermore, we find that dexamethasone inhibits sodium channel induction but not neurite outgrowth. These results suggest that morphology and sodium channel expression are regulated independently and must involve, at least in part, distinct mechanisms. The sodium channel must belong to the class of transcripts reported by Leonard et al. (1987) and Stein et al. (1988) that are FGF and NGF inducible and dexamethasone suppressible. In contrast, some gene products associated with neurite outgrowth might belong to the class of transcripts described by Leonard et al. (1987) that are NGF inducible but not dexamethasone suppressible. Alternatively, neurite outgrowth may require posttranslational modifications of gene products that might not be responsive to glucocorticoids. The differences between the effects of NGF and FGF on neurite outgrowth may similarly result from a differential activation of some genes or different posttranslational mechanisms. Whatever the mechanism, our data show that not all components of neuronal differentiation need to respond equally to a particular agent and, therefore, that different elements of a neuronal phenotype can be independently regulated by the microenvironment. This emphasizes the complexity of neuronal differentiation, evident in the various phenotypes obtained even by just comparing, quantitatively, 2 components of the cell. It gives an indication of how the microenvironment, containing different mixtures of effectors, might regulate different phenotypes. This complexity can be understood in terms of the converging and diverging signal pathways of different growth factors and the presence of multiple regulating elements in genes. The ability of the local milieu to regulate cell morphology independently of sodium channel expression could have impor- 

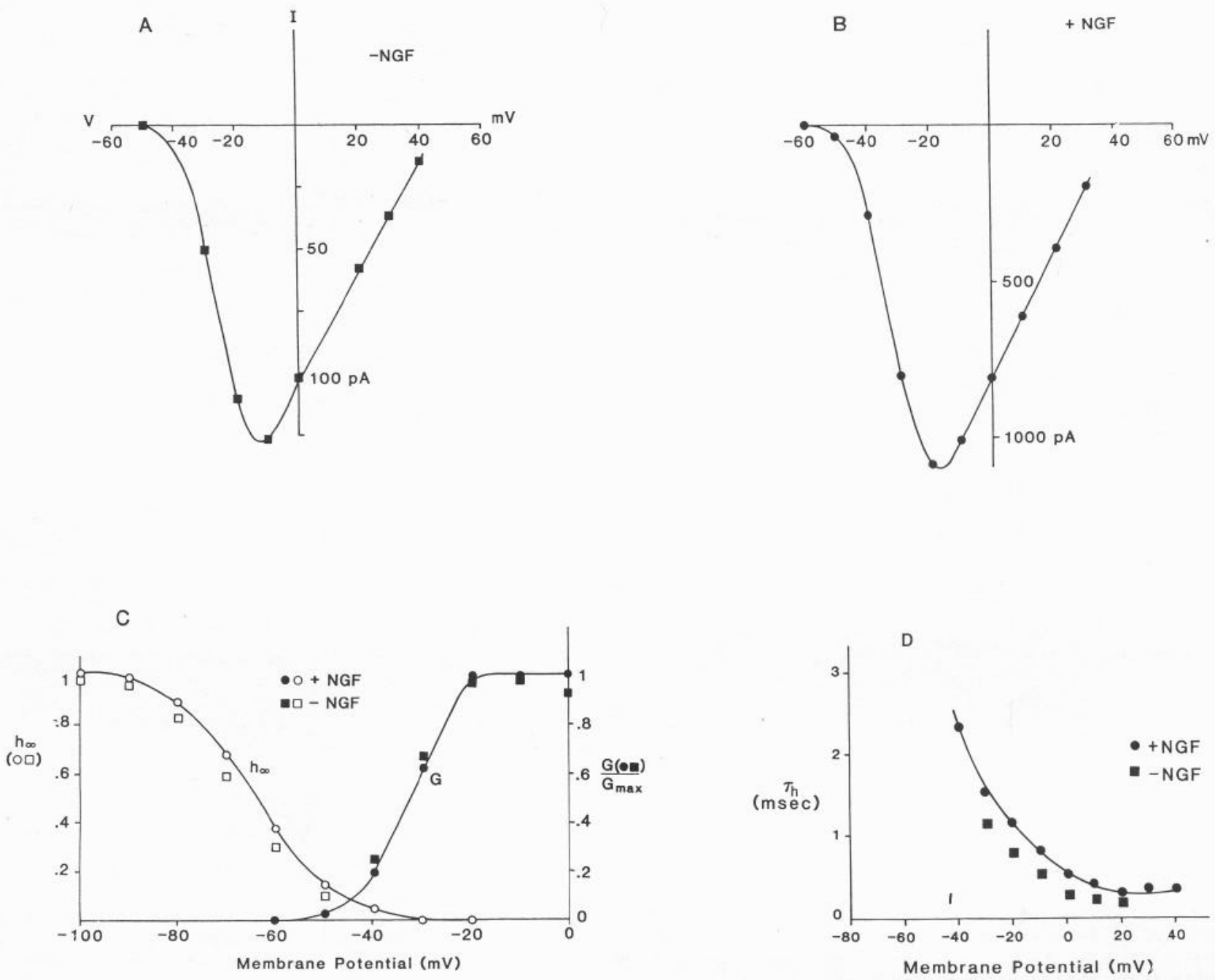

Figure 5. Macroscopic properties of sodium currents in PC12 cells. Data were derived from records of the difference current obtained before and after the application of $1 \mu \mathrm{M}$ TTX. $A$ and $B$, Current-voltage relation for the $-\mathrm{NGF}(A)$ and the $+\mathrm{NGF}(B)$ cells. $C$, Voltage dependence of the sodium conductance (closed symbols) and voltage dependence of steady-state inactivation (open symbols) for the $-\mathrm{NGF}($ squares) and $+\mathrm{NGF}$ (circles) cells. The conductance was obtained assuming a constant reversal potential of $+50 \mathrm{mV}$ and is plotted as a relative conductance (i.e., the conductance at the indicated voltage divided by the maximum conductance obtained at large depolarizations). Steady-state inactivation was obtained from the ratio of the peak current obtained at $+20 \mathrm{mV}$ over that obtained at the same membrane potential in a pulse preceded by a 100 msec prepulse to the indicated voltage. $D$. Time constants of inactivation as a function of voltage obtained by fitting, to a single exponential, the decay of the sodium current during a depolarizing pulse to the indicated voltage.

2 DAYS NGF

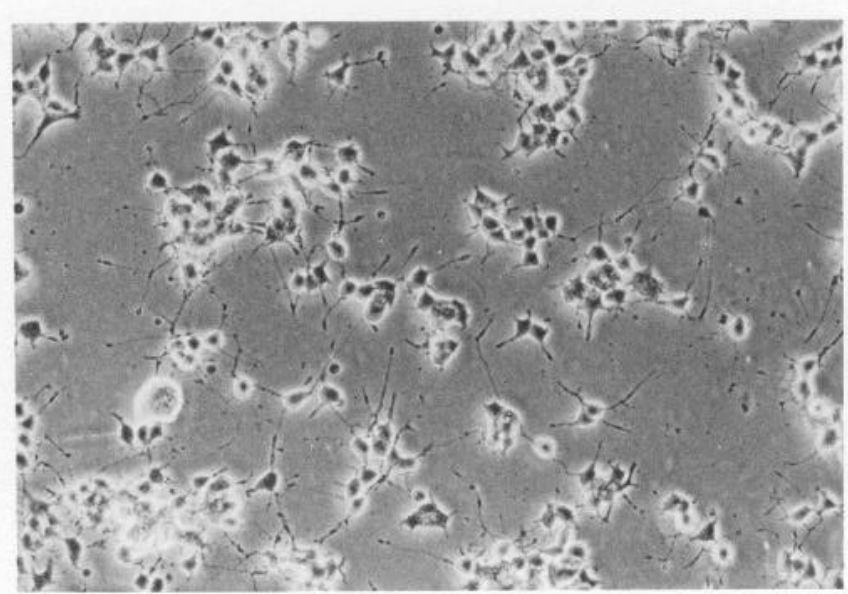

2 DAYS NGF+ DEX

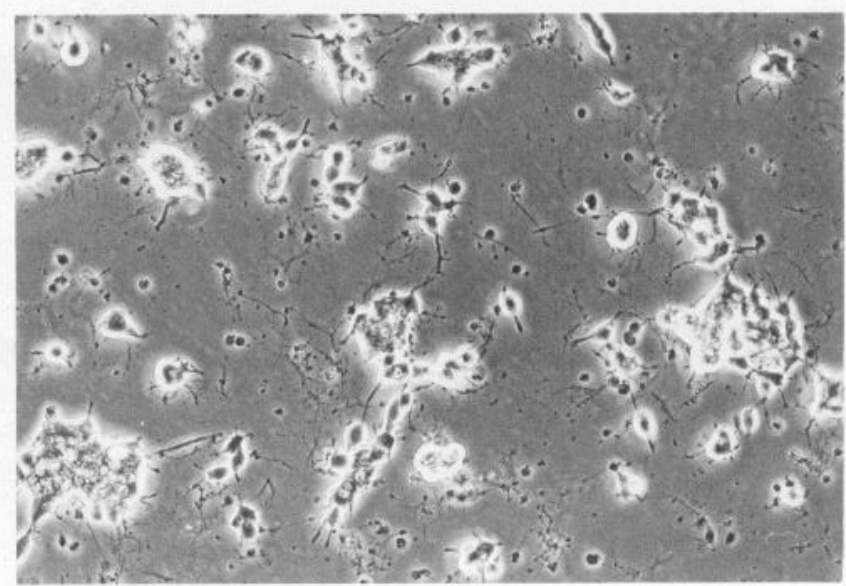



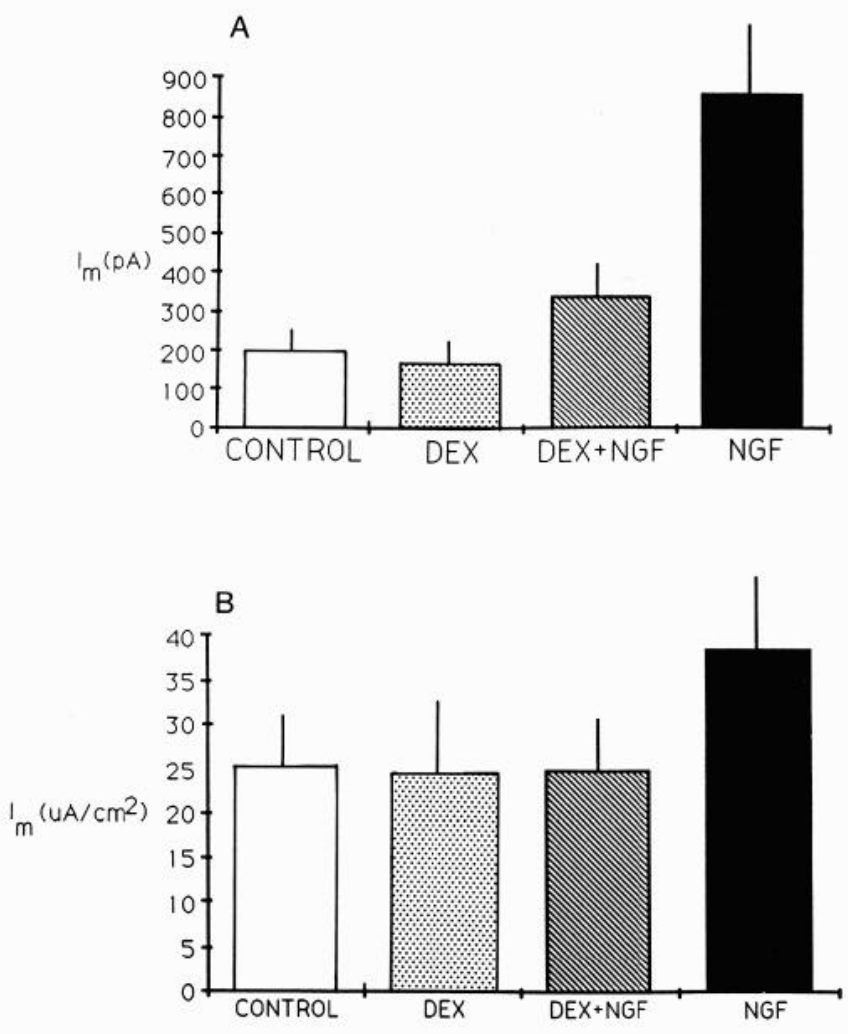

Figure 7. Dexamethasone $(5 \mu \mathrm{M})$ inhibits peak sodium current $(A)$ and peak sodium current density $(B)$ of $\mathrm{PC} 12$ cells treated with $50 \mathrm{ng} / \mathrm{ml}$ NGF for $2 \mathrm{~d}$. Average from 12 cells (control), 13 cells (dexamethasone), 12 cells (dexamethasone + NGF), 10 cells (NGF). Error bars: SEM.

tant consequences for active and passive electrical properties of neurons.

The signal-transduction pathways used by NGF, FGF, and EGF to induce sodium channel expression remain a mystery. cAMP has been suggested as a mediator of some of the effects of NGF (Schubert et al., 1978; Garrels and Schubert, 1979; Halegoua and Patrick, 1980; Cremins et al., 1986). Our data indicate that cAMP cannot act as a major second messenger for sodium channel induction by NGF, FGF, or EGF in PC1 2 cells since treatment of the cells with this agent leads to a decrease in sodium current. This is in contrast to the effects of cAMP on developing muscle cells (Offord and Catterall, 1989), where sodium channel message and protein are increased by cAMP. This suggests the existence of several sodium channels genes regulated by different factors. The inhibition of sodium current by cAMP is similar to the results observed by Greene et al. (1986) and Doherty et al. (1987), who found that pretreatment with forskolin or cholera toxin, both activators of adenylate cyclase, blocked several NGF-induced responses in PC12 cells. Moreover, these results indicate that any activation of adenylate cyclase by NGF or FGF is by itself insufficient to explain differentiation and may even lead to inhibition of some of the events initiated by NGF and FGF. Interestingly, we find that cAMP produces an increase in calcium current. It is well known that
cAMP increases the opening probability of certain types of calcium channels (Reuter, 1983; Tsien, 1983). This is an immediate and short-lasting effect. Our data suggest that cAMP may also produce, in some cells, a long-term increase of calcium current density by regulating the numbers of expressed channels.

Note Added in Proof: Contrary to the observations described here, Kalman et al. (1990) found that cAMP produçes an increase in $\mathrm{Na}^{+}$currents in PC1 2 cells. They suggest that the NGF increase in $\mathrm{Na}^{+}$channel numbers involves the activation of cAMP-dependent protein kinase. We note, however, that the induction of $\mathrm{Na}^{+}$currents by either cAMP or by NGF reported by Kalman et al. is about an order of magnitude smaller than that observed by us after NGF or FGF treatment. Furthermore, while we observed a large increase in $\mathrm{Na}^{+}$current density after NGF or FGF treatment, their treated cells have current magnitudes similar to those of untreated cells that express $\mathrm{Na}^{+}$currents. It is possible that $\mathrm{PC} 12$ cells have 2 mechanisms to regulate $\mathrm{Na}^{+}$channel numbers. Other proteins are regulated by cAMP-dependent protein kinase in PC12 cells (see Discussion). However, the large induction of $\mathrm{Na}^{+}$channels described here and in previous publications (Rudy et al., 1982, 1987), like the NGF-induction of several other late genes in PC12 cells, appears not to be mediated by cAMP.

\section{References}

Aletta JM, Angeletti R, Liem RKH, Purcell C, Shelanski ML, Greene LA (1988) Relationship between the nerve growth factor-regulated clone 73 gene product and the 58-kilodalton neuronal intermediate filament protein (Peripherin). J Neurochem 51:1317-1320.

Barde Y-A (1989) Trophic factors and neuronal survival. Neuron 2: $1525-1534$.

Basi GS, Jacobson RD, Virag I, Schilling J, Skene JHP (1987) Primary structure and transcriptional regulation of GAP-43, a protein associated with nerve growth. Cell 49:785-791.

Claude P, Parada IM, Gordon KA, D'Amore PA, Wagner JA (1988) Acidic fibroblast growth factor stimulates adrenal chromaffin cells to proliferate and to extend neurites but is not a long term survival factor. Neuron 1:783-790.

Connolly JL, Greene LA, Viscarello RR, Riley WD (1979) Rapid, sequential changes in surface morphology of $\mathrm{PC1} 2$ pheochromocytoma cells in response to nerve growth factor. J Cell Biol 82:820-827.

Connolly JL, Green SA, Greene LA (1984) Comparison of rapid changes in surface morphology and coated pit formation of PC12 cells in response to nerve growth factor, epidermal growth factor, and dibutyryl cAMP. J Cell Biol 98:457-465.

Contreras ML, Guroff G (1987) Calcium-dependent nerve growth factor-stimulated hydrolysis of phosphoinositides in PC12 cells. J Neurochem 48:1466-1472.

Cremins J, Wagner JA, Halegoua S (1986) Nerve growth factor action is mediated by cyclic AMP and $\mathrm{Ca}$ /phospholipid dependent protein kinases. J Cell Biol 103:887-893.

Curran T, Franza BR Jr (1988) Fos and Jun: the AP-1 connection. Cell 55:395-397.

Curran T, Morgan JI (1985) Superinduction of c-fos by nerve growth factor in the presence of peripherally active benzodiazepines. Science 229:1265-1268.

Dichter MA, Tischler AS, Greene LA (1977) Nerve growth factorinduced increase in electrical excitability and acetylcholine sensitivity of a rat pheochromocytoma cell line. Nature 268:501-504.

Dickson JG, Prentice H, Julien JP, Ferrari G, Leon A, Walsh FS (1986)

Figure 6. Effect of dexamethasone on neurite outgrowth in cells treated with NGF for $2 \mathrm{~d}$. Comparison of PC12 cell cultures treated with 50 ng/ $\mathrm{ml} \mathrm{NGF}$ for $2 \mathrm{~d}$ (left) with cells treated with NGF for $2 \mathrm{~d}$ in the presence of $5 \mu \mathrm{M}$ dexamethasone (right). 
Nerve growth factor activates Thy-1 and neurofilament gene transcription in rat PC12 cells. EMBO 5:3449-3453.

Distel RJ, Ro HS, Rosen BS, Groves DL, Spiegelman BM (1987) Nucleoprotein complexes that regulate gene expression in adipocyte differentiation: direct participation of $c$-fos. Cell 49:835-844.

Doherty P, Mann DA, Walsh FS (1987) Cholera toxin and dibutyryl cyclic AMP inhibit the expression of neurofilament protein induced by nerve growth factor in cultures of naive and primed PC1 2 cells. J Neurochem 49:1676-1687.

Doupe AJ, Landis SC, Patterson PH (1985) Environmental influences in the development of neural crest derivatives: glucocorticoids, growth factors, and chromaffin cell plasticity. J Neurosci 5:2119-2142.

Drubin DG, Feinstein SC, Shooter EM, Kirschner MW (1985) Nerve growth factor-induced neurite outgrowth in PC12 cells involves the coordinate induction of microtubule assembly and assembly-promoting factors. J Cell Biol 101:1799-1807.

End D, Tolson N, Hashimoto S, Guroff G (1983) Nerve growth factorinduced decrease in the cell-free phosphorylation of a soluble protein in PC12 cells. J Biol Chem 258:6549-6555.

Federoff HJ, Grabczyk E, Fishman MC (1988) Dual regulation of Gap43 gene expression by nerve growth factor and glucocorticoids. J Biol Chem 263:19290-19295.

Garrels JI, Schubert D (1979) Modulation of protein synthesis by nerve growth factor. J Biol Chem 254:7978-7985.

Gospodarowicz D, Neufeld G, Schweigerer L (1986) Molecular and biological characterization of fibroblast growth factor, an angiogenic factor which also controls the proliferation and differentiation of mesoderm and neuroectoderm derived cells. Cell Differ 19:1-17.

Greenberg ME, Greene LA, Ziff EB (1985) Nerve growth factor and epidermal growth factor induce rapid and transient changes in protooncogene transcription in PC12 cells. J Biol Chem 260:14101-14110.

Greene LA (1984) The importance of both early and delayed-responses in the biological action of nerve growth-factor. Trends Neurosci 7: 91-94.

Greene LA, Tischler AS (1976) Establishment of a noradrenergic clonal line of rat adrenal pheochromocytoma cells which respond to nerve growth factor. Proc Natl Acad Sci USA 73:2424-2428.

Greene LA, Tischler AS (1982) PC12 cultures in neurobiological research. Adv Cell Neurobiol 3:373-414.

Greene LA, Drexler SA, Connolly JL, Rukenstein A, Green SH (1986) Selective inhibition of responses to nerve growth factor and of microtubule-associated protein phosphorylation by activators of adenylate cyclase. J Cell Biol 103:1967-1978.

Greene LA, Aletta JM, Rukenstein A, Green SH (1987) PC12 pheochromocytoma cells: culture, nerve growth factor treatment, and experimental exploitation. Methods Enzymol 147:207-216.

Halegoua S, Patrick J (1980) Nerve growth factor mediates phosphorylation of specific proteins. Cell 22:571-581.

IIamill OP, Marty A, Neher E, Sakmann B, Sigworth FJ (1981) Improved patch-clamp techniques for high-resolution current recording from cells and cell-free membrane patches. Pfluegers Arch 391:85100 .

Kalman D, Bradley W, Horvai AE, Kline MJ, O'Lague PH (1990) Nerve growth factor acts through cAMP-dependent protein kinase to increase the number of sodium channels. Neuron 4: 355-366.

Karns LR, Ng SC, Freeman JA, Fishman M (1987) Cloning of complementary DNA for GAP-43, a neuronal growth-related protein. Science 236:597-600.

Kirschenbaum B, Snutch T, Lester H, Greene LA, Davidson N, Rudy B (1987) Induction of Na channels and Na channel mRNA by NGF in PC12 cells. Soc Neurosci Abst 13:795.

Kruijer W, Schubert D, Verma IM (1985) Induction of the protooncogene fos by nerve growth factor. Proc Natl Acad Sci USA 82: $7330-7334$.

Landis SC, Patterson PH (1981) Neural crest cell lineages. Trends Neurosci 4:172-175.

Landreth GE, Rieser GD (1985) Nerve growth factor- and epidermal growth factor-stimulated phosphorylation of a PC12 cytoskeletally associated protein in situ. J Cell Biol 100:677-683.

Le Douarin NM (1980) The ontogeny of the neural crest in avian embryo chimeras. Nature 286:663-669.

Le Douarin NM (1982) The neural crest. Cambridge, UK: Cambridge University Press.

Lee MY, Page C (1984) The dynamics of nerve growth factor-induced neurofilament and vimentin filament expression and organization in PC12 cells. J Neurosci 4:1705-1714.
Leonard DG, Ziff EB, Greene LA (1987) Identification and characterization of mRNAs regulated by nerve growth factor in PC1 2 cells. Mol Cell Biol 7:3156-3167.

Levi A, Eldridge JD, Paterson BM (1985) Molecular cloning of a gene sequence regulated by nerve growth factor. Science 229:393-395.

Logan A, Logan SD (1986) Distribution of fibroblast growth factor in the central and peripheral ncrvous systems of various mammals. Neurosci Lett 69:162-165.

Lucas CA, Czlonkowska A, Kruetzberg GW (1980) Regulation of acetylcholinesterase by nerve growth factor in pheochromocytoma PC12 cell lines. Neurosci Lett 18:333-337.

Mandel G, Cooperman SS, Maue RA, Goodman RH, Brehm P (1988) Selective induction of brain type II $\mathrm{Na}^{+}$channels by nerve growth factor. Proc Natl Acad Sci USA 85:924-928.

McGuire JC, Green LA (1979) Rapid stimulation by nerve growth factor of amino acid uptake by clonal PC12 pheochromocytoma cells. J Biol Chem 254:3362-3367.

Milbrandt J (1986) Nerve growth factor rapidly induces c-fos mRNA in PC12 rat pheochromocytoma cells. Proc Natl Acad Sci USA 83: 4789-4793

Mobley WC, Schenker A, Shooter EM (1976) Characterization and isolation of proteolytically modified nerve growth factor. Biochemistry 15:5543-5552.

Neufeld G, Gospodarowicz D, Dodge L, Fujii DK (1987) Heparin modulation of neurotropic effects of acidic and basic fibroblast growth factors and nerve growth factor on PC12 cells. J Cell Physiol 131: 131-140.

Offord J, Catterall W (1989) Electrical activity, cAMP, and cytosolic calcium regulate mRNA encoding sodium channel $\alpha$ subunits in rat muscle cells. Neuron 2:1447-1452.

Reuter H (1983) Ca channel modulation by neurotransmitters, enzymes and drugs. Nature 301:569-574.

Richter-Landsberg C, Greene LA, Shelanski ML (1985) Cell surface Thy-1-cross-reactive glycoprotein in culture PCl 2 cells: modulation by nerve growth factor and association with the cytoskcleton. J Neurosci $5: 468-476$.

Rieger F, Shelanski ML, Greene LA (1980) The effects of nerve growth factor on acetylcholinesterase and its multiple forms in cultures of rat pheochromocytoma cells: increase total specific activity and appearance of the 16S molecular form. Dev Biol 76:238-243.

Romano C, Nichols RA, Greengard P, Greene LA (1987) Synapsin I in $\mathrm{PCl} 2$ cells I. Characterization of the phosphoprotein and effect of chronic NGF treatment. J Neurosci 7:1294-1299.

Rowland EA, Muller TH, Goldstein M, Greene LA (1987) Cell free detection and characterization of a novel growth factor activated protein kinase in PC12 cells. J Biol Chem 262:7504-7513.

Rudy B, Kirschenbaum B, Greene LA (1982) Nerve growth factorinduced increase in saxitoxin binding to rat $\mathrm{PC} 12$ pheochromocytoma cells. J Neurosci 2:1405-1411.

Rudy B, Kirschenbaum B, Rukenstein A, Greene LA (1987) Nerve growth factor increases the number of functional $\mathrm{Na}$ channels and induces TTX-resistant Na channels in PC12 pheochromocytoma cells. J Neurosci 7:1613-1625.

Rydel RE, Greene LA (1987) Acidic and basic fibroblast growth factors promote stable neurite outgrowth and neuronal differentiation in cultures of PC12 cells. J Neurosci 7:3639-3653.

Salton SR, Richter-Landsberg C, Greene LA, Shelanski ML (1983) Nerve growth factor-inducible large external (NILE) glycoprotein: studies of a central and peripheral neuronal marker. J Neurosci 3: $441-454$.

Schubert D, La Corbiere M, Whitlock C, Stallcup W (1978) Alterations in the surface properties of cells responsive to nerve growth factor. Nature 273:718-723.

Schubert D, Ling N, Baird A (1987) Multiple influences of a heparinbinding growth factor on neuronal development. J Cell Biol 104:635643.

Stein R, Orit S, Anderson DJ (1988) The induction of a neural-specific gene, SCG-10, by nerve growth factor in PC12 cells is transcriptional, protein synthesis dependent, and glucocorticoid inhibitable. Dev Biol 127:316-325.

Stemple DL, Mahanthappa NK, Anderson DJ (1988) Basic FGF induces neuronal differentiation, cell division, and NGF dependence in chromaffin cells: a sequence of events in sympathetic development. Neuron 1:517-525.

Tischler AS, Perlman RL, Nunnemacher G, Morse GM, DeLellis RA, Wolfe HJ, Sheard BE (1982) Long-term effects of dexamethasone 
and nerve growth-factor on adrenal medullary cells cultured from young adult rats. Cell Tissue Res 225:525-542.

Tischler AS, Lee YC, Costopoulos D, Slayton VW, Jason WJ, Bloom SR (1986) Cooperative regulation of neurotensin content in PC12 pheochromocytoma cell cultures: effects of nerve growth factor, dexamethasone, and activators of adenylate cyclase. J Neurosci 6:1719. 1725.

Togari A, Dickens G, Kuzuya H, Guroff G (1985) The effect of fibroblast growth factor on PC12 cells. J Neurosci 5:307-316.

Tsien RW (1983) Ca channels in excitable cell membranes. Annu Rev Physiol 45:341-358.
Unsicker K, Kirsch B, Otten U, Thoenen H (1978) Nerve growth factor-induced fiber outgrowth from isolated rat adrenal chromaffin cells: impairment by glucocorticoids. Proc Natl Acad Sci USA 75: 3498-3502.

Wagner JA, D'Amore P (1986) Neurite outgrowth induced by an endothelial cell mitogen isolated from retina. J Cell Biol 103:13631367.

Yu MW, Tolson NW, Guroff G (1980) Increased phosphorylation of specific nuclear proteins in superior cervical ganglia and PC12 cells in response to nerve growth factor. J Biol Chem 255:10481-10492. 